\title{
It Has Always Been A Man's World: The Woman As Other In The Shona And Ndebele Proverb
}

\author{
Jacob Mapara \\ Chinhoyi University of Technology Institute of Lifelong Learning \\ Centre for Indigenous Knowledge and Living Heritage Zimbabwe \\ Research Fellow: UNISA, College of Human Sciences \\ Department of African Languages, South Africa \\ jacob.mapara@gmail.com, jacomapara@yahoo.co.uk,jmapara@cut.ac.zw
}

\author{
Simangenkosi Thebe \\ Great Zimbabwe University Zimbabwe \\ cemathebe@gmail.com
}

\begin{abstract}
The paper argues that despite assertions that have been made in some circles that women have been treated as equal to men in pre-colonial Zimbabwe, an analysis of both Shona and Ndebele proverbs yields evidence that is to the contrary. It goes on to argue that both Shona and Ndebele societies have been patriarchal and have remained so up to this day. The researchers posit that these proverbs that have continued to be taught in Zimbabwean schools have been more of a celebration of the marginalisation of women than a celebration of culture. It argues that this is so because the proverbs have entrenched in the psyche of the young learners the erroneous notion of male superiority where the woman is perceived as the other while the man is the human being. The paper further argues that the way females are presented in both Shona and Ndebele proverbs is counterproductive since it conflicts with issues of gender and equality where women are accepted as equals, and yet the proverbs present them not only as lesser human but also in some instances as sex objects.
\end{abstract}

\section{INTRODUCTION}

The study of the Shona and Ndebele/Zulu proverb has attracted the attention of several scholars; among them are Hamutyinei and Plangger (1987), Fortune (1975; 1985), Chimhundu (1980) and Pongweni (1989) well as Nyembezi (1990). These studies have tended to concentrate on classifying the proverbs according to their social function as Chimhundu does or according to their morphological as well as aesthetic function as Fortune, Pongweni, Hamutyinei and Plangger do. Devlieger (1999) has focused on how African proverbs, including the Shona and Ndebele ones can be used to pay attention to civil rights and participation of persons with disabilities in the mainstream of society (1999: 439). This study examines Shona and Ndebele proverbs with human imagery found in inventories of the Shona and Ndebele proverb such as Hamutyinei and Plangger (1987), Nyembezi (1990) and Pelling (1977) as well as from proverbs heard in general use. These earlier studies of the Shona and Ndebele proverb have motivated the current research whose point of departure is that it is a sociolinguistic study of the proverb and gender. The proverb has been defined as an important aspect of language use in society. It is prominent within the Bantu societies. The proverb can be used to actively introduce, conclude or stress a point in conversation. It can also be used by the powerful in their aspirations to control and impose their given view of life as unshakeable and acceptable (Ssetuba 2005:37). This paper builds on that foundation and examines some Shona 
and Ndebele proverbs to help to establish and consolidate particular kinds of identity for women and men in the Shona-Ndebele society. It thus seeks to foreground what the proverb says about the Shona and Ndebele people's sensitivity or insensitivity to females and males. The paper argues that the Shona and Ndebele proverb, which originates in a highly patriarchal society, creates and perpetuates gender stereotypes. Stereotype has been defined as "... a set of characteristics which describe a prototype that is a typical member" (Crystal, 1991:320). Similarly, the Cambridge Learner's Dictionary (Gillard, 2001:626-627) defines stereotype as “... a fixed idea about a type of person or thing, which is often not true in reality".

\section{Justification of the study}

This study focuses on Ndebele and Shona proverbs and not on one language only. The reason for this is clear. The two languages and cultures in Zimbabwe are usually perceived as mutually exclusive due to the colonial policy of divide and rule that created a chasm between the two peoples. Most Shona have always believed that the Ndebele were always hostile and were bent on taking their cattle and women. In actual fact, the Shona themselves also raided one another for the same reasons that the Ndebele are alleged to have raided them (Schmidt 1992). The Ndebele themselves have not made the situation any better. They have also bought into the colonial lie that they were the better of the two ethnic groups. Mazarire adds on to this by observing:

We are now clear that relations between the Ndebele and their neighbours were not necessarily antagonistic all the time but sometimes mutual, even where they were indeed antagonistic the Ndebele were not always the victors (2003: 3).

These observations are important in that the present the Ndebele more as human beings and as well as people who could also be defeated. It also dispels the lie that the Shona were always at the mercy of the Ndebele.

In addition to the historical imperatives, there are also the linguistic and cultural links between the two. Linguistically they are both Bantu languages, although they do belong to different groups. Shona is in the S10 group of Bantu while Ndebele is in the S44 group. Besides all belonging to the Bantu languages family, the two also have some cultural similarities. Religiously they all believe in ancestral spirits referred to as amadlozi in Ndebele, and as midzimu among the Shona. In both groups, the family plays an important role in the primary socialization of children and both have an agricultural base that is anchored on tilling the land and supported by animal husbandry.

An analysis of the above therefore shows that a comparative analysis of how these two groups harness proverbs to entrench patriarchy is justifiable.

\section{RESEARCH METHOD}

This research used a qualitative approach. This involved text analysis as well as sampling of the proverbs for scrutiny. Because the researchers deliberately picked out some proverbs for detailed study, purposive sampling was used. In purposive sampling there is a deliberate effort by the researcher to actively select the most productive sample to answer the research question. This involves among others the development of a framework of variables that might influence an individual's contribution. It will in most cases be based on the researcher's practical knowledge of the research area in addition to the available literature and evidence from the study itself. Purposive sampling is the only viable sampling technique in obtaining information from a very specific group of people. 


\section{THEORETICAL FRAMEWORK}

This paper is informed by feminism. The crucial initiative of feminism rests on the argument that men and women are equal. It however rests on the thesis that women are unjustly and unfairly treated by their male counterparts. Feminism is nonetheless not a homogenous movement. It has several versions that are based not only on continental basis, but also on racial ones. There is American feminism that is classified into three historical phases that are referred to as waves. The thrust of this study will not focus on the other two versions, the British and French ones, but on the American one that the researchers feel has a direct bearing on this paper because of Black Feminism that later evolved into Africana Womanism. But before moving to these, the paper would first focus on three models that relate to feminism and that attempt to explain why women are subordinated to men. These are the deficit, dominance and difference models.

These are models used in analysing language and gender differences in sociolinguistics (Thorne and Henley 1975; Talbot 1998). The deficit approach perceives the asymmetrical relations in language used by men and women and about men and women as a result of women's differences. For instance, Lakoff (1975) says that men's language is viewed as the natural one while that of women as the deviation or one reflecting deficiency from the norm. Lakoff concludes that women are socially conditioned to be different and that difference makes them deficient and unequal to men.

There are others who subscribe to the dominance approach, argue that the differences are a result of power differences between men and women (West 1975, 1984 and Fishman 1980, 1983). This model sees socialization as a crucial gender constructing process. According to this model, the girl child learns female roles and rules because she is a female while the boy learns male rules and roles because he is a male (West and Zimmerman 1987). These authorities see gender as methodical as they argue thus “... a person's gender is not simply an aspect of what one is but more fundamentally, it is something that one does and does recurrently in interaction with others" (West and Zimmerman 1983: 140). They argue that as girls learn solidarity, the boys learn dominance. That is, boys/men are socially given skills of 'dominance' while the girl/women are socially given skills that please the men and hence of subservience.

Tannen (1990) studied the American society and emphasizes the difference position. She comes to the conclusion that men and women are different but equal. For Tannen, American girls and boys, "... grow up in different worlds, therefore sex differences can be seen as culture differences and consequently cross-sex communication is seen as cross-cultural communication" (Tannen 1990: 250). Tannen's argument is based on the assumption that in cross-cultural or inter-cultural communication members from different cultures will bring their own norms and rules of communication and apply them for comprehension purposes. Tannen takes this hypothesis to gender on the assumption that women and men come from different sociolinguistic sub-cultures. The difference approach is also referred to as 'the subcultural' or 'two cultures approach'. Tannen further argues that if society understood these differences then men and women would be 'equal' but different in that they come from different sub-cultures.

The three models discussed above have been used on gender and language studies and they have also attracted the attention of critics. The deficit and difference models have been criticised for not realizing that the differences between men and women arise from inequality and not the other way round (Cameron, 1998 and Uchida, 1992). Secondly, the two models are silent on the issue of power in men and women interaction. Thirdly, language and gender 
researchers criticise the deficit model for its patriarchal tendencies that fail to recognize women and their styles as equal to men and their styles. Talbot (1990) argues that the difference model is attractive to politically moderate researchers because it is tolerant and reconciliatory and does not put blame on anyone unlike the dominance model. In the sociolinguistic tradition, the difference model is seen as neutral while inequality is seen as a result of suppression (Cameron, 1998: 42 and Talbot, 1998: 133). The poststructuralists also question the power imbalance of the dominance approach. These models help in giving a platform to analyse feminism in proper perspective. The feminist movement which has evolved over the years has its origins way back in the 19th Century. Its progeny, Black feminism, womanism and African Womanism are the products of the third wave of feminism as it unfolded in the United States.

The first phase of the feminist movement dealt with women's basic rights, for example the right of women to vote and be elected to political office. The second phase, exemplified by the thoughts of Simone de Beauvoir in her book The Second Sex (1973) and her quote "One is not born, but rather becomes, a woman" (1973: 301), brought about the questioning of cultural and societal norms. The second wave covered the period from the 1960s through to the late 1980s. The second wave was largely dominated by among other issues those that dealt with equality, such as well as ending discrimination.

Third wave feminism began around the early 1990s. It emerged as a reaction to perceived failures of the second phase. It was as well a response to the backlash against initiatives and movements created by the second wave. Third-wave feminism challenges and seeks to avoid what it deems the second wave's essentialist definitions of femininity, which (according to them) over-emphasize the experiences of upper middle-class white women http://www.gender.cawater-info.net/knowledge_base/rubricator/feminism_e.htm. The third wave has also seen the rise of what is called by its proponents, Africana womanism, because the Blacks feel that they have suffered not only from racial bigotry at the hands of Whites, both male and female, and that they have also been victims of patriarchy.

Although there have been efforts to separate womanism, Black feminism and Africana Womanism, a detailed analysis of it shows Africana Womanism is a version of Black Feminism that has emerged in the United States where most females of colour feel that they have suffered double oppression and discrimination at the hands of Whites, both male and female, as well as patriarchy at the hands of White men and Black men. The term womanism was first coined by African American writer and feminist activist Alice Walker (Davidson and Davidson 2010: 239). She used the term in reference to a black feminist or feminist of colour who loves other women, sexually and/or non-sexually. Womanism as well appreciates and prefers women's culture although there are also expressions for the loves of individual men, sexually and/or non-sexually. It is a theory that is committed to the survival and wholeness of all people, male and female. Womanism attempts to address the otherwise separatist nature of feminism by recognizing men as partners rather than foes. The major proponent of African Womanism is Clenora Hudson-Weems.

Despite the similarities that exist between black feminism and womanism, and Africana Womanism, a major constituent in Africana Womanism is that Africana Women are expected to act in concert with male struggles (Hudson-Weems 1993: 61). It dovetails with black feminism, by moving away from the white patriarchal values posed by feminism (Hudson Weems 4). Conversely, according to Hudson-Weems, black feminism diverges from Africana Womanism because it reveals a "lack of African-centered historical and contemporary perspective [and is] unsuccessful in galvanizing the majority of African American women as feminists" to resolve 
problems within the black community" (Hudson-Weems 1993: 27). The main objective of the Africana Womanist is to abet in bringing to fruition the independence and authenticity of the African race (Hudson-Weems 1993: 51). Her aim is to bring all African Americans together as one unified body that will be turn out to be perceptible to the dictatorial and racist as well as arrogant white majority.

The Africana Womanist is one who names herself (Hudson-Weems 1993: 55). She is the one who creates her identity and does not leave that task in the hands of her oppressors as has been happening for generations. The term Africana therefore refers to the ethnicity of the women whose origins are in Africa. Womanism on the other hand identifies a female of the human race, while female can include all species (Hudson-Weems 1993: 22-23). What all the above isms have shown is the engagements that women have had in an effort to have a fair playing field with their male counterparts. For the Black women of African (Africana) descent, it is also an issue of self-naming and curving out an identity for oneself as well as struggling together with fellow black man against racism as practiced by both white males and females on them. Linked to all the above are the post-structuralist models as well as the issue of gender.

\section{THE POSTSTRUCTURALISTS MODELS}

The poststructuralists include Foucault (1989), Kress (1985) and Mills (2002). These focus on individuals and diversity in society rather than groups such as males and females. For Mills, patriarchy is no longer a factor in gender and language since emphasis now falls on individuals than on groups. Mills sees three waves to do with language and gender namely, the first, second and third waves. Mills argues that the first wave was concerned with differences between females and males, in the second wave, feminists demanded equal treatment with males and the third wave is a result of criticisms of current theories that have been about white middle class women (see Bucholtz, 1999). Mills stresses that identity is not given but is negotiated through handling power relations during interactions. Mills further argues that patriarchy is no longer an issue thus he discredits the difference and the dominance models. Mills' argument shows that the poststructuralists recognize power in discourse but their approach recognises shifts in different discourses by individuals (Crawford, 1995), rather than in groups as in the dominance model (Kitzinger, 1991). The poststructuralists argue that individuals when managing different subjects in different contexts create identities. Foucault stresses that identities such as feminine and masculine are socially constructed. They point out that power is also created in discourse and is not a property of the so-called powerful such as men and the rich. The present researchers feel that these critical discourse analysts are relevant here only to some extent as far as they argue that history and society are crucial factors in delimiting gender. However, their argument that power is not a property of the powerful groups but that it is negotiated in interactions is not fully African. Such negotiations may have been reached in the Western world contexts but the same cannot be said of a patriarchal community like the Shona-Ndebele one under consideration here. Patriarchy is still very relevant among the Shona-Ndebele since people are socially grouped by gender. Furthermore, this culture has pregiven elements where people, especially women are concerned (Gombe, 1998; Hodza 1987:45; Chiwara, 1980:266-67; Mhondoro, 1980:265; Ranger, 1993; Chinyowa, 1997). What is true of Shona culture can also be said to be true of Ndebele. If there are differences, these are minor. Performed or negotiated gender identities as in critical discourse analysis are rejected or ridiculed for going against given the grain. For example, independent professional chief executive Shona-Ndebele women are often disparaged for doing what men do (see Mashiri, 2002; Chitauro, 2002) and are said to have slept their way to the top. They are not appreciated. What this shows is that poststructuralist ideas may be found among some Shona-Ndebele professional women, but this culture is still a 
practicing patriarchy where men dominate. Some cultural institutions such as the proverb under consideration in this paper promote male dominance. Thus, the Shona-Ndebele context suggests dominance and deficit as the main factors in affecting differences between sexes. The difference, however, is found to be useful to some extent since it does not show that socialisation is dictated by power and dominance and that difference is a result of dominance.

What comes clearly out of all these theories and despite the fact that Africana womanism attempts to present men as equals of women and that women should join men in their struggles, the reality on the ground and in Zimbabwe for that matter is that women are still treated as second class citizens and as people who are there to serve the interests of men and not their own. This is clearly borne out by marriages that were conducted in the pre-colonial periods where they served more as diplomatic fronts than romantic relations. This is clearly captured by Vengeyi (2014: 64) who gives an example of Jezebel who got married to Ahab for political reasons. He states:

However, what we need to realise is that marriages were part of the diplomatic system. This is why kings always married (sic) daughters of kings of surrounding nations. The wives were sort of ambassadors of their own countries.

These words are quite telling. It is clear that since time immemorial, women have always served the interests of men. Men, it appears, have never treated women as equals. Here in Zimbabwe, there is the legend of Makate and Nehoreka. The story is similar to the biblical one of Samson and Delilah (Judges 16: 1-31). Nehoreka who desired to take Makate's land tried to invade the territory. He was overcome because Makate had powerful medicine (makona). Nehoreka learnt his lesson but did not give up. He encouraged his sister who was very beautiful. Makate fell for her and when she was with Makate she learnt all his secrets and where he kept his makona. After she had armed herself with this medicine, she escaped and gave these to her brother. When Nehoreka invaded again, Makate realised that he had been tricked by his wife. He fled with his people http://oxfordindex.oup.com/view/10.1093/oi/authority.20110803100227563. In this legend, it is clear that a woman is used to serve the needs of a man, and she does so willingly. She is subordinate to a man. Related to this is the case of the Mutasa Dynasty. There was in precolonial Mutasa chieftainship, a practice where daughters of royal families were given areas of jurisdiction. Any man who got married to any one of these women was by extension meant to serve the interests of the Chief and the Mutasa royalty in general. While on the surface it would appear as if women had power, in reality, the power that they wielded was that which enabled them to serve their male kith and kin. In the light of the above it becomes clear that it is naive to romanticise the past and present pre-colonial men as having treated their women with respect and saw them as equals. If anything, they used women and also feared them as 'foreigners' who had the power to destabilise their adopted families. They were and still are treated with suspicion. These issues that are historically embedded have for a long time been buried under the onslaught on colonialism and its influence on male Blacks. They show that while Black men discriminated against their female counterparts, their segregation and abuse of women only worsened as a result of colonialism. Colonialism made Black males not only subservient to white men but also to the white women. In these circumstances, the issue of gender becomes more complex.

\section{GENDER IDENTITY}

The current researchers realise that in social life people are categorized into social structures. These structures assign them to specific social duties and roles. With that in mind, the researchers examine how the Shona and Ndebele proverb helps to establish and consolidate 
particular kinds of identity for men and women (gender) in the society. Linguists normally perceive gender as a grammatical category. However, in this paper gender is taken as a social category. Gender is also often confused with sex (that is female and male). While sex is biologically founded, "Gender by contrast is socially constructed; it is learned" (Talbot, 1998:7). Sex basically refers to biological differences as well as genetic ones between men and women. Gender on the other hand is about functions at the household, community, and national levels. It is embedded in each society's social, cultural, economic and political systems.

The current researchers assert that gender is an important division among the Shona and the Ndebele just as it is in all societies. The Shona and Ndebele proverbs examined here demonstrate how being born Shona-Ndebele male or female has far-reaching ramifications. It can affect the way people use language or the way language is used about them. It can also affect whether one is going to be sent to school or not, or determine the type of school one is sent to. This paper looks at the social divisions of gender and the part the Shona and Ndebele languages in general and the proverb in particular plays in establishing and maintaining these divisions. As Talbot (1998:14) specifies, "Language simply reflects society, so that social divisions on gender grounds are reflected in patterns of language use." The current researchers posit that the proverbs also play a complex part alongside other social practices and institutions in creating, reflecting and reinforcing gender divisions in the society. Shona and Ndebele proverbs like all proverbs are said to be coined from the experiences of people as they observe life, and for this reason, they are described as statements of general truths (Chimhundu, 1980). Wolfgang defines the proverb as a short, generally known sentence of folk, which contains wisdom, truths, morals and traditional views in a metaphorical, fixed and memorisable form and which is handed down from generation to generation (2004: 1). Pelling (1977:5) concurs with the above words by observing that a proverb is usually economic in its use of language, and often rhythmical in formation, making it thus easy to remember and say. The imagery in proverbs includes that of human beings as well as that of the flora and fauna in their environment. The proverb has two meanings, namely the literal that relies on the imagery in the proverb, and the culturally deeper meaning or interpretative meaning that is generalized. For example, the Ndebele proverb:

1. Amagundwane amanengi kawalamlindi.

Literal (Lit): Many rats have no burrow.

Interpretation (Int): There must always be a leader in a group or one to take responsibility.

In order to highlight what the Shona and Ndebele proverbs say about these people's sensitivity to females and males, the current researchers analysed Shona and Ndebele proverbs with human imagery. These proverbs show how the Shona-Ndebele males and females are socialised. The researchers deliberately compared such proverbs on four plains, namely women as witches, as sex objects and inferior and women as foolish. By woman is here meant females of all ages. This article has benefited a lot from insights from the deficit, dominance and difference and the poststructuralists models. The word other is here used to mean a being who is perceived as less human.

\section{What a proverb is?}

A proverb represents a succinct, metrically well thought-out, figurative expression. It is capable for polysemantic use according to the principle of analogy. E.g. the proverb "Gudo hariramwirwi munda" (You cannot give up your field because of a baboon) is interesting not because of its express meaning but by that it may be applied to other similar situations. The 
subject of the statement is considered in the light of a generally accepted fact expressed by a proverb. This renders it ideological and emotional. The proverb is in addition to what has been presented above, the epitome of a people's philosophy (Abayomi https://www.academia.edu/3396925/Philosophy_in_African_Proverbs). It shows the ability of not only the Shona and Ndebele but all humanity to express their inner most thoughts, feelings and sensations through a keen and very sharp sense of imagination. It is through the application of proverbs that a speaker is able to touch some nerve, or very inner spot of some people. It is part and parcel of every community, whether oral or literary. Proverbs are the depository of each people's wisdom. Through them one can read back into deem mists of history as in proverbs like Pakaputsika dende rine mukaka (There was the breaking of a gourd full of milk).

Proverbs fall under what Barber calls oral texts together with other forms of literature (2007: 66-7). As regards proverbs alone, she points out that the quotedness of proverbs is a signal that they are utterances that are constituted to solicit for comments, analysis, and assessment. The assessment does not only focus on the performance, but also on the text itself, since the oral text is perceived as a detachable autonomous formulation that has to be captured and grounded by the user but which is defined, by the users themselves, precisely as utterance which escapes total definition by its context (Barber 2007: 77). These views are quite interesting especially when applied to the Zimbabwean context. What she observes does not always follow because when the proverbs that are taught in schools are interpreted, this is done out of context and the images that they carry are usually the same that are used to interpret them. This has a bearing in some instances where some proverbs have images of women. For example, Mukadzi wemumwe ndiambuya (Another man's wife, is one's mother-inlaw). In most cases teachers would interpret it to mean exactly that, that another man's wife is the other's mother in-law. Students hardly think beyond the fact that the proverb when used in a context where one is being chastised for theft may mean that $\mathrm{s} /$ he has to respect private property. They hardly think this way, because most teachers use the images that are given in the proverbs to literary explain the meanings carried in the proverbs. This has the sad result that the images of women that are used in these proverbs are perceived as reflections of women or how they should be treated. It is these images that the researchers attempt to bring to the attention of other readers so that they realize that the Zimbabwean school curriculum for Shona and Ndebele has perpetuated the notion and belief that women are inferior and are passive objects that only come to life after being switched on by men.

\section{The proverb in the Zimbabwean school curriculum}

The teaching of the proverb to students in the Zimbabwean schools starts as early as the third grade. In fact, most parents are bombarded by homework on proverbs that some of them can hardly understand, let alone interpret. The interpretation that is given to most of these proverbs is usually literal, with most meanings coming from the images that are in the same proverbs. The following proverb in Shona would serve as a very good example:

\section{Chembere mukadzi, hazvienzani nekurara mugota}

(Literal: It is better to have an elderly woman for a wife than to sleep alone. Interpretation/meaning: It is better to have something that is sub-standard than have nothing (Half a loaf is better than none).

Most teachers explain this proverb using the literal meaning. It is this meaning that gets entrenched in the minds of most students that they grow up with the image of women as sex objects no matter their age. This has adverse effect on male-female relations because at the end schools which are secondary socialisation agents end up entrenching gender stereotypes 
instead of getting rid of them. There is therefore need to revise the way proverbs are taught in schools. They have to be taught in context, not out of context as is currently the case at all levels from the third grade in primary school, to Ordinary level where proverbs are even examined in the school General Certificate of Education (GCE). It may also become necessary to prescribe the types of proverbs that have to be taught. This is so because those that may lead to gender stereotyping will have to be left until at later stages where pupils would be in a better position to understand that the use of certain images is there only to help drive home a given idea or ideas.

\section{Women as witches}

Generally women among the Shona and Ndebele are perceived as witches. In fact, the perception is so entrenched that when people talk of witches or pupils in schools are asked to draw a witch (muroyi/umthakathi) they would draw an image of a woman usually riding on the back of a hyena, and at times accompanied by owls. This view of women as witches is prevalent the world over, because the talk and debate is always on witchcraft and not wizardry, a form of witchcraft that is performed by men. This means that the focus is more on women and how they are believed to be practitioners and perpetrators of this science that is largely seen as evil. The conception of women as witches is captured in some proverbs that are found among both the Shona and the Ndebele. The following proverbs bring this out.

1. Nhenha isingabi ingoroya (A beautiful girl who is not a thief is a witch).

2. Mukadzi wenhaka rova wakafunga, tsvimbo wakakupa asi gona wakasara naro (If you think of beating up an inherited wife you have to consider that decision carefully, she gave you the staff, but she kept her horn for witchcraft).

3. Mai kuba, mukunda kuroya (While the mother is a thief, the daughter is a witch).

4. Rakaipa nderokuroya, rokuvhima ishave roumhare (What is bad [alien spirit] is that of witchcraft while that one for hunting is of expertise).

5. Umswane wembabala kawungeniswa ekhaya

In the first proverb, the emphasis is not on the woman's physical beauty, but on theft and witchcraft. This proverb makes it very clear that among the Shona and the Ndebele physical beauty in a woman is not that which is strongly celebrated. It is even in some instances viewed as a bad omen since beautiful women are viewed as dangerous because they can cause calamities to befall those who associate with them. They are never trusted because they are viewed as people who can be either thieves or witches. Today an additional vice has been added to beautiful women - they can be prostitutes. The effect of the imagery of women as witches and thieves is that males will view women as a necessary evil that they only have to get married to because they need children as well as recreation. In fact, the perception of women as bad if not completely evil is underlined by the car sticker that reads, "If God created something better than a woman, he kept it for himself." The proverb goes on to reinforce the generally held view among men of women as witches. In Zimbabwe's Mashonaland West Province there is a town called Karoi (Small/Little witch). The coat of arms of this town is that of a witch riding on a broomstick. While the idea of witches and broomsticks is western, because for Zimbabwe witches are associated with hyenas and owls, the most important aspect to note about this coat of arms is that it has the image of an old woman thus further entrenching the misconception that women, especially old and ugly ones are witches.

The second one cautions men that they have to be careful in the way they deal with inherited wives. The point that comes out strongly is that one has to consider carefully the potential consequences if he decides to chastise her, especially by hitting her. This comes out in the idea 
that even though she gave her new husband her late husband's tsvimbo (multipurpose stick for walking and fighting) as a public sign that she was choosing him as her new husband, she did not hand over her horn of witchcraft (gona). The implication of the proverb is therefore that the first husband may have died after witchcraft had been administered to him after he had disappointed his wife. The effect of this proverb is that it tends to stigmatise widows as witches and therefore minimises their chances of getting married again for those who would possibly opt for this.

In the third proverb, the perception of women that is presented is that both mothers and their daughters are not good people. Mothers are presented as bad examples to their daughters such that the result is that their daughters become worse than them. In the imagery used in the proverb, while a mother becomes a thief, which is heavily frowned upon for a woman to do, her daughter becomes a witch. The daughters become worse than thieves when compared to their mothers because they can do more harm than their mothers since they become thieves of a special kind - they can steal lives if they so choose.

The fourth proverb highlights the differences between males and females. Traditionally, males are hunters, and among them are found expert hunters (vahombarume). Females on the other hand are mostly perceived as witches. The result of these perceptions is that women are looked upon with fear because they are considered to be potential life takers at worst, or people who can bring harm at best. The implication of the imagery is that it entrenches the generally held stereotypical thinking that men are better women since according to this proverb they are providers. This is so because men go out and hunt for animals whose flesh is meant to feed people, while women are less human because they bring harm and death into the world through their perceived nefarious acts of witchcraft.

The fifth proverb shows that there are very few proverbs among the Ndebele that deal with the issue of witchcraft. What however, comes out clearly is that the Ndebele, like their Shona counterparts also perceive women as witches. This proverb is about advice that is given to a young man who has fallen in love with a young woman whom he intends to get married to. He is being advised to first find out about her parents looking for information on whether her parents are not witchcraft practitioners. The fear is that if one or all of her parents dabbles in witchcraft, then the suitor's family will perish since she will bring with her the science of witchcraft. This proverb does not openly use images that refer to a woman as a witch as happens among the Shona. However, a closer analysis of the idea reveals that a woman has the potential to become a witch echoes through it.

\section{Women as sex objects}

Men the world over have traditionally viewed women as sex objects that are there for their sexual gratification. This comes out clearly even in everyday language where men talk of women as sex objects. It is common to hear a man say to a colleague, 'Musikana uya ndakazomuisa' (I finally inserted [my male organ into] her). These words give the impression of the woman as a passive object in the whole sexual act. There is also a song by an urban groover in Zimbabwe Crystal Crystals who sings, 'Toyi yangu, bhebhi yangu' (My toy, my babe). These examples serve to point out that women are perceived as sex objects that are there for the enjoyment of men.

The idea of women as sex objects is captured in the proverbs that follow:

6. Mukadzi mumwe inhekwe yomubindwa ikakochekera pamuti unosara wava mukuna (One wife is like a snuff container that you hang on your neck, if it gets entangled in a thicket, you will be left naked). 
7. Kunyenga mvana ita mbiri, ukarambwa neimwe unosara neimwe (Propose love to two single mothers so that if one ditches you, you will remain with another.

8. Kuramba mvana hunge uine mhandara (To reject a single mother it is because you have a maid/virgin).

9. Nzenza mumvuri asvika anowosa zuva (A sexually lose woman is a tree shade, anyone who passes by gets protection from the sun).

10. Ikhakasi limuka nomoya (The thistle is carried by the wind).

The sixth and seventh proverbs highlight the importance of polygamy or having multiple sexual partners to men. The sixth proverb gives the impression and warning that if one was to lose a wife, he would be in a very precarious and dangerous predicament if he had one wife. It would be better therefore if a man was to have more than one wife. This is collaborated by the image of nakedness (mukuna) that is given in the proverb. Therefore, the only way a man can avoid this potential nakedness is for him to have more than one wife or lover/girlfriend.

The seventh proverb encourages extramarital affairs among married men, and several affairs among the single ones. The term mvana in Shona is used to refer to an unmarried woman who has had a child/children out of wedlock. The situation of mvana therefore makes them potential targets for men who would be in search of both short and medium term sexual relationships. Men are therefore encouraged to have affairs with at least two single mothers or any single women who may not be mothers. The purpose is to ensure that a man never runs short of a sexual partner besides his wife/wives. Interestingly, there are no proverbs that have images where women are encouraged to have other lovers besides their husbands or the ones they are engaged to.

In the eighth proverb, a young woman who is without child, most likely a virgin, has her value over the one who has a child or children highlighted. The idea behind the image is that of one who is in pristine condition, one who has not been tempered with. In short, men enjoy deflowering virgins even if they may not be virgins themselves. The underlying message that however comes out of this same proverb is that for sexual satisfaction, in the absence of a maid/virgin, a single mother is second best.

The proverb Nzenza mumvuri asvika anowosa zuva (A sexually lose woman is a tree shade, anyone who passes by gets protection from the sun) buttresses the value of women as sex objects in the eyes of men. Nzenza in Shona is a term that is used to refer to a woman or women who cannot turn down sexual advances from any man. Her readiness to accept any man who approaches her for his sexual gratification is what has led to her being compared to a tree whose shade anyone can take refuge in. The refuge in the case of this woman comes in the form of a man's sexual gratification on the part of the man who would have bedded her.

The tenth proverb is similar to the eleventh one. Although it may describe a person who is easily swayed by other people's opinions, it is normally used to refer to a woman who has a weakness for men. The fact that men see a weakness in her and thus approach her for sexual favours shows that she is viewed by these same men as a sex symbol.

\section{Women as foolish}

At times women are portrayed in images that entrench in the minds of the hearers, especially young ones, as people who are downright foolish and are therefore buffoons and imbeciles. They are presented as behaving in ways that defy logic and are a potential threat to their future 
and that of others. The folly that women are perceived to have is highlighted in the following proverbs and also in the explanations to their meanings:

11. Ibele lendlela kalivuthwa (The grain corn that is on the path doesn't ripen).

12. Kakikho ntombi yagana inyamazana (No girl fell in love with an animal).

13. Usenga inkomo, asenge inkonyane (He milks the cow and then the calf).

14. Kushaya nzero kwemhandara kupfumbira sadza chibhakira (It is lack of wisdom for a maid to threaten sadza with her fist).

15. Mafutura avakatanga kuturikidza svinga nechirongo (It is folly for those who came first to put a pitcher on a bundle of wood on their heads).

The above proverbs show women as dimwits. They leave a lot to be desired. In fact, proverb eleven warns young women against giving themselves cheaply to men because they will at the end fail to get husbands. The woman who gives herself cheaply to men is compared to a grain of corn that has fallen on the path. It is folly for a young woman to be like that grain of corn. While the proverb is but just a warning, it is important to note that proverbs are products of observations that some people would have made over long periods. It is a result of these observations that men may have concluded that women have a propensity for folly because they at times give themselves cheaply to men and the result is that at the end they fail to secure marriage partners.

The twelfth proverb sees folly in a young woman who waits for Mr. Right to come her way before she commits herself to marriage. The meaning of the proverb is that the young woman who waits for the ideal husband will wait forever because such people do not exist. The message that is given in the proverb is that it is those women who wait who are foolish because they fail to realise and understand that ideal men only exist in people's fantasies. The proverb makes it appear as if it is only young women who are foolish for waiting for Mr. Right, yet there are also some young men who also wait for their ideal women but unfortunately for them these do not turn up.

The target of the thirteenth proverb is a man who has sexual relations with a woman and her daughter. However, the people who are portrayed as foolish are the mother and daughter because they are going out with the same man. The folly of the women comes out in the sense that obviously one of them knows that the other one is going out with a particular man. If it is the mother, it is the daughter who would be highlighting the height of folly if she goes out with her mother's boyfriend. The same is equally true if the mother also goes out with her daughter's lover.

It is important to note that for proverb fourteen, women are not mentioned by name, but culturally it is known that women carry bundles of firewood as well as fetch water for household use. The proverb therefore portrays women as people who become overconfident on matters that require caution. Instead of carrying each of these two separately, the woman is being presented displaying the height of her folly when she combines the two unrelated loads, one which is easily breakable (the water pitcher), and the other that is not (the bundle of firewood). Like in the other proverbs above, this one goes a long way in highlighting the fact that this world is dominated by men because the images that are carried in the proverbs prove this. They have the effect of showing women not only as foolish but also as inferior as is shown in the next segment.

\section{Women as inferior to men}

The idea of the inferiority of women in short means that men or most men are of the opinion that they are better beings than women whom they label as less human. In Shona and Ndebele 
culture women are viewed as inferior to men. It is not uncommon to hear men ask one another, 'Vakadzi vanhu here?' (Are women human beings?). Similarly among the Ndebele, the person in a family who is considered to be the real Ndebele is the man who is head of the house. In fact, in both cultures, women are seen as perpetually children. As a result of this perception several proverbs were coined that present women as inferior to men.

16. Chakadya ndebvu dzevakadzi ndichowo chakadya mazamu evarume (What ate the women's beards also ate the men's breasts).

17. Murume ijongwe rinofa richiita (A man is a cock, he continues to have sexual intercourse even in old age until he dies).

18. Mwanarume ihona yeutare (A boy child is like a bone of iron).

19. Kakuqhalaqhala lehlula isidwaba (No cocksure girl has beaten the skin skirt).

20. Iliba lendoda kalaziwa (The grave of a man is not known).

21. Inxele kaliwubusi umuzi (A fist does not build a home)

22. Khala mfazi ongazalanga (Cry barren/childless woman)

23. Amankonyane akhethwa kubonina (The calves are chosen from the midst of their mothers)

Proverb sixteen is on the surface innocent. It is referring to the fact that men generally grow beards while women grow breasts. Unfortunately this biological and genetic difference has been exploited by men who take these natural differences to mean that men are superior to women.

The seventeenth proverb does not use any female image. It in fact uses the male one. It portrays males as biologically superior to women, and therefore are the 'real' human beings because they get to their deaths whilst scientifically being sexually active and reproductive unlike women whose reproductive period ends around forty-five years. Men have interpreted this to mean that they are therefore better than women because the women's reproductive span is short-lived.

In the eighteenth proverb, the boy child is compared to a bone of processed iron. Iron was very important in the Early Iron Age since it played a significant role agricultural revolution in precolonial Africa. As a result of iron, populations grew and those who could control the production of iron became very powerful and rich. Therefore the comparison of the boy child to iron means that he is perceived as one of the mainstays of the family as compared to the girl child who would get married and is described in another proverb as a caster seed that scatters. She therefore does not build the family. She contributes towards the growth of another family, not her own. This use of the image that compares the boy child to a bone of iron has led most people to consider the girl child as less important when compared to the boy. This therefore means that even boys would see themselves as superior to their sisters.

Proverb nineteen is basically about men always celebrating a young woman's loss of independence when she gets married. The proverb means that it is marriage that terms a confident and 'wild' young woman. The fact that in the explanation of this proverb a woman is referred to as 'wild' and 'young' means that she is being described in animalistic terms that she is presented as inferior and base. She needs to be tamed so that she at least understands and appreciates a human being, who in this case is the man.

The proverb Iliba lendoda kalaziwa (The grave of a man is not known) means that the role of a man is that of supporting and defending his family and ethnic group. It therefore means that 
since it was considered honourable among men for one to die in battle, to die at home at an active age for a male was viewed as having died as a woman. This was especially so if one died in a raid. According to this proverb, women are the ones who were supposed to die at home because they did not have the skills or the courage to face the enemy in the field of battle. This was so because women were considered as inferior.

The twenty-first proverb is used in reference to an abusive husband. The sense behind the proverb is that real men talk to their wives. It is women who are driven by emotions and not reason who end resorting to violence or verbal abuse. In short, the proverb is stating that one would be lowering himself to a status similar to that of a woman if he resorts to the use of fists to solve his domestic problems. The proverb is also used to encourage men to avoid taking advice from their wives because they are not considered part of the family. In fact, among the Ndebele and the Shona a woman is considered a foreigner in her own family. The Budya of Mutoko in Mashonaland East province go even further. When a man's wife dies, her remains are interred at her parents' home, and not at her new home that she would have built with her husband. Among the Ndebele, the woman's being a foreigner even in her own home is made clear in the statement Umfazi ngumuntu wokuza. The Shona also state this idea of the woman's being a foreigner through the words, Mukadzi mutorwa. Another pointer to the wife's being a foreigner is highlighted by the fact that children take their father's family name and totem.

Proverb twenty-two is about a woman who is being laughed at by society because she is childless. If she had children, her children would have helped in her hour of need. It is important to note here that 'society' is largely patriarchal, thus it is therefore men who laugh at women who are perceived to be unable to conceive. The men always blame women for failure to conceive even if they are the ones who may be at fault. This perception of females as largely barren has led a lot of men to view women as inferior.

The twenty-third proverb deals with the issue of courtship. It compares young women to calves that are assessed in their kraal. The idea behind this proverb is that when a young man goes out looking for a suitable marriage partner, he usually approaches the young woman at her parents' home and makes his intentions clear. In the Ndebele tradition, such a young man would get the approval of the targeted young woman's parents. The approval was given even if the woman was not interested in the suitor. The idea of women as inferior comes out in the fact that the woman is denied a chance to make her own choice. She therefore becomes an unwilling partner whose feelings and views are not worth considering.

\section{CONCLUSION}

The discussion has demonstrated that although the Ndebele and Shona proverbs' role is to mediate social relations and reflect on Ndebele-Shona culture, they end entrenching gender roles and stereotypes. The paper established that the Ndebele-Shona institution of the proverb treats males and females differently. The differences are seen in the categories that have been discussed above. These categories are not exhaustive and they are interwoven. The imagery that is used in these proverbs is heavily tilted in favour of the males who are shown as dominant and superior, which makes them 'different' from their female counterparts. The females on the other hand are portrayed negatively and in a manner that does not make most young women and girls appreciate their uniqueness as well as the positive contributions that they can make for the betterment of other people's lives. Proverbs with male imagery generally present males positively and as adventurous and brave fighters, for example, Iliba lendoda kalaziwa (The grave of a man is not known) and Kufa kwemurume kubuda ura (A man dies by being disembowelled). These examples and many others used about the males in this paper give and celebrate male attributes such as virility, bravery and being superior. On the other 
hand the female imagery used portrays the females as sex objects, inferior and as witches. They are also presented as people who are there to be defended and are not to be listened to. Besides these, women are also presented as foolish. The imagery that society uses also portrays the females as people who have a deficiency. It is this perceived deficiency that makes the males to categorise and label them as different and inferior when compared to their male counterparts. Women are almost always portrayed negatively and mainly in a subordinate and objective position. It is this portrayal of women that makes the researchers to conclude that the position and perception of women is already predetermined by a Ndebele-Shona patriarchal society that respects men more than it does women. For example, the Shona proverb musha mukadzi determines what the woman's role should be or is in the home, while it is silent on what is expected of the man's role in that same home. The research has established that women are viewed as passive objects that are there for men and they only become active when activated by men. This is made clear in the proverbs that deal with the females and their sexuality. They have no control over it but it is there for men. The following proverbs make this clear: Kunyenga mvana ita mbiri, ukarambwa neimwe unosara neimwe (Propose love to two single mothers so that if one ditches you, you will remain with another) and Amankonyane akhethwa kubonina (The calves are chosen from the midst of their mothers)

All in all, the researchers conclude that Ndebele-Shona proverbs with human imagery socially give skills of dominance to boys/males while the girls/females are given skills that please the men and hence of subservience and inferiority. The researchers found out that this is possible because as Cameron (1985: 2) observed on the English language, the Ndebele-Shona proverb, which is an aspect of the Ndebele and Shona languages, is part of patriarchy and it thus plays a significant role in maintaining male power.

\section{References}

Abayomi, 0. Philosophy in African Proverbs.

https://www.academia.edu/3396925/Philosophy_in_African_Proverbs Accessed on 09 December 2014.

Barber, K. 2007. The Anthropology of Texts, Persons and Publics. Cambridge: Cambridge

University Press.

Bucholtz, M. 1996. “Black Feminist Theory and African American women's linguistic practice”. In Bergvall, Bing and Freed 1996.

Cameron, D. 1985. Feminism and Linguistic Theory. London and Basingstoke:

Macmillan Press.

Cameron, D. 1998. The Feminist Critique of Language: A Reader. London: Routeledge.

Chimhundu, H. 1980. Shumo-Tsumo and Socialization. Zambezia 8 (1): 37-51.

Chimhundu, H. 1987. Language, Literature and Sex stereotypes. Paper presented at the PWPA Annual Conference, Siavonga. Zambia.

Chitauro, B. 2002. Gender Sensitivity in Language use: A Lexicographical and Corpusbased Study of Words in Context. Unpublished PhD. thesis. Oslo: University of Oslo. Chiwara, R. 1980. Umhandara hwako Ruvimbo. In Haasbroek, J. (Editor). Nduri dzeNhango dzomuZimbabwe. Gweru: Mambo Press. Pp 266-67.

Crawford, M. 1995. Talking Difference: On Gender and Language. London: Sage.

Crystal, D. 1991. The Cambridge Encyclopaedia of Language (reprint). Cambridge:

CUP. 
Davidson, M. and Davidson S. 2010. “Perspectives on Womanism, Black Feminism, and

Africana Womanism" In African American Studies Volume: Introducing Ethnic Studies Series, ed. Jeanette R. Davidson. Edinburgh: Edinburgh University Press, Pp 239-259.

De Beauvoir, S. 1973. The Second Sex. New York: Vintage Books.

Devlieger, P.J., 2010. Frames of Reference in African Proverbs on Disability. In International Journal of Disability, Development and Education.

http://www.pdfserve.informaworld.com/88616_788609065_713671091.pdf Accessed 05 September 2010.

Firth, G. 1993. Women, Writing and Language: Making the Silences Speak. In

Richardson, D. and Robinson, V. (Eds) Thinhking Feminist: Key Concepts in Women's Studies. New York: The Guilford Press. Pp 151-176.

Fortune, G. 1975-6. Form and imagery in Shona proverbs. Zambezia 4 (2): 27-55.

Fortune, G. 1985. Shona Grammatical Constructions Volume II. Harare: Mercury Press.

Gaidzanwa, R. 1985. Images of Women in Zimbabwean Literature. Harare: College

Press.

Gillard, P. 2001. (Senior commissioning editor) Cambridge Learner's Dictionary. Cambridge and New York: Cambridge University Press.

Gombe, J.M. 1998. Tsika dzaVaShona. Harare: College Press.

Hamutyinei, M.A. \& Plangger, A.B. 1987. Tsumo-Shumo: Shona Proverbial Lore and

Wisdom. Gweru: Mambo Press.

Hodza, A.C. 1987. Ugo Hwamadzinza aVaShona. Harare: Mercury Press.

Hudson-Weems, C. 1993. Africana Womanism: Reclaiming Ourselves. Troy: Bedford

Publishers, INC.

Kress, G. 1985. Linguistic Processes in Sociocultural Practices. Victoria: Deakin

University Press.

Malmkjaer, K. 1991. Language and Gender. In The Linguistics Encyclopaedia. Edited by K. Malmkjaer. London and New York: Routledge.

Mashiri, P. \& Warinda, C. 1999. Dudziramutauro re“A” level. Gweru: Mambo Press.

Mazarire, G. 2003. "Who are the Ndebele and the Kalanga in Zimbabwe?” Paper Prepared for

Konrad Adenuer Foundation Project on 'Ethnicity in Zimbabwe' November.

http://ir.uz.ac.zw/jspui/bitstream/10646/314/1/Mazarire-Ndebele-and-Kalanga.pdf Accessed on 04 December 2014.

Mhondoro, K. 1980. Ndiko kunonzi kunyengwa here? In Haasbroek, J (Editor). Nduri

dzeNhango dzomuZimbabwe. Gweru: Mambo Press. Pp 265-66.

Nyota, S. 1999. Dudziramutauro re“O” level. Harare: Academic Books.

Nyota, S. \& Mapara, J. 2007. Language as Indigenous Knowledge. Cape Town:

CASAS.

Nyembezi, C.L.S. 2000. Zulu Proverbs. Pietermaritzburg: Shuter and Shooter.

Oxford University. Nehoreka Learns His Enemy's Secret. In A Dictionary of African

Mythology. http://oxfordindex.oup.com/view/10.1093/oi/authority.20110803100227563 Accessed on 08 December 2014.

Pelling, J. 2000. Ndebele Proverbs and Other sayings. Salisbury: Longman.

Pongweni, A.J.C. 1989. Figurative Language in Shona Discourse. Gweru: Mambo Press. 
Richardson, D. 1993. Sexuality and Male Dominance. In Richardson, D. and Robinson,

V. (Eds) Thinhking Feminist: Key Concepts in Women's Studies. New York: The Guilford Press. Pp 74-98.

Schmidt, E. 1992. Peasants, traders, and wives: Shona women in the history of Zimbabwe,

1870-1939. Harare: Baobab Books.

Schur, E.M. 1983. Labelling Women Deviant: Gender, Stigma and Social control.

Philadelphia: Temple University Press.

Spender, D. 1985. Man-made Language. London: Routledge and Kegan Paul.

Ssetuba, I. 2005. The hold of Patriarchy: An Appraisal of the Ganda Proverb in Modern

Gender Relations. In le Roux, E., M.A.J. Ndeda, G. Nyamndi, F.E.M.K. Senkoro and I. Ssetuba. Gender, Literature and Religion in Africa. Dakar: Codesria. Pp 37-47.

Talbot, M.M. 1998. Language and gender: An Introduction. Cambridge: Polity Press.

Tannen, D. 1990. Gender differences in conversational coherence, physical alignment

and topical cohesion. In Conversational Organization and its Development. Edited by B. Dorval. Norwood NJ: Ablex.

Tannen, D. 1991. You Just don't understand: Women and Men in Conversation. New

York: Ballantine Books.

Uchida, Aki. 1992. When 'difference is dominance': A critique of the 'anti-power based' cultural approach to sex differences. Language in Society 21:547-68.

Vengeyi, 0. 2014. Land as an Inalienable Asset: Lessons from I Kings 21: 1-29. In Mararike,

C.G. (Editor). Land: An Empowerment Asset for Africa - The Human Factor Perspective. Harare: University of Zimbabwe Publications. Pp 59-79. 